\title{
DESARROLLO DE ESTADIOS ASEXUALES DE Sarcocystis aucheniae EN CULTIVO DE CÉLULAS
}

\author{
Development of Asexual Stages of Sarcocystis aucheniae in Cell \\ Culture
}

Milagros Uzuriaga S. ${ }^{1}$, Rosa Sam T. ${ }^{1,3}$, Alberto Manchego S. ${ }^{1}$ y Arnaldo Alvarado S. ${ }^{2}$

\section{RESUMEN}

\begin{abstract}
Cistozoitos obtenidos a partir de macroquistes de Sarcocystis aucheniae presentes en carne de alpacas con sarcocistiosis fueron inoculados en cultivo primario de células de cornete nasal de feto de alpaca (CNA) y en líneas de células establecidas de riñón de bovino (BHK) y de mono (VERO). Los cistozoitos ingresaron a todas las células, transformándose en grandes y pequeños esquizontes multinucleares o en estadios como quistes, produciendo gran cantidad de merozoitos, todos de posición perinuclear. Cultivos continuos a partir del inóculo original de cistozoitos fueron mantenidos por más de 150 días por subcultivo de cistozoitos sobre nuevos cultivos de células CNA, BHK y VERO. Durante este tiempo, se mantuvo la capacidad de producir ambos tipos de esquizontes. Se confirmó la reproducción de los cistozoitos por tinción Giemsa y mediante inmunofluorescencia e inmunoperoxidasa, ambas pruebas utilizando antisuero anti $S$. aucheniae producido en conejos.
\end{abstract}

Palabras clave: alpaca, Sarcocystis, cultivo de tejidos, inmunoperoxidasa, inmunofluorescencia

\section{Abstract}

Cystozoites obtained from macrocysts of Sarcocystis aucheniae, collected from alpaca meat infected with sarcocystiosis, were inoculated onto primary monolayer cultures of alpaca turbinate (AT) and secondary monolayer of bovine kidney (BHK) and monkey kidney (VERO) cells. Sporozoites entered the cells, formed large and small multinucleate schizonts, and produced large numbers of cystozoites of perinuclear position. Continuous cultivation from the original cystozoite inoculum was maintained for more than 150 days by inoculating cystozoites onto new cultures of AT, BHK and VERO cells. During this time, the capacity to produce both types of schizonts was preserved. The reproduction of cystozoites of S. aucheniae in tissue culture was confirmed using the Giemsa stain and the fluorescence microscopy and immunoperoxidase test, both of them, using antibodies anti $S$. aucheniae produced in rabbit.

Key words: alpaca, Sarcocystis, tissue culture, immunoperoxidase, immunoflourescence

\footnotetext{
${ }^{1}$ Laboratorio de Microbiología y Parasitología Veterinaria, ${ }^{2}$ Laboratorio de Patología Clínica, Facultad de Medicina Veterinaria, Universidad Nacional Mayor de San Marcos, Lima

${ }^{3}$ E-mail: kueylan@hotmail.com
} 


\section{INTRODUCCIÓN}

La sarcocistiosis, enfermedad de gran importancia en camélidos sudamericanos, es producida por la coccidia Sarcocystis aucheniae (Moro y Guerrero, 1971). Se le señala como el segundo causal de decomiso de carcasas de alpacas debido a la presencia de macroquistes en la musculatura. Estos quistes pueden llegar a medir $1 \mathrm{~cm}$ de largo y producir pérdidas de $900 \mathrm{TM}$ por año en el camal de Santa Rosa, Puno (Alva et al.,1980).

La ruta de transmisión del S. aucheniae es vía fecal-oral por transferencia de esporoquistes a partir de caninos (Sam, 1988). La patogénesis de la infección en alpacas (Lama pacos) y llamas (Lama glama), hospedadores intermediarios naturales, incluye exquistación de ooquistes en el intestino delgado e invasión de células intestinales con cistozoitos que realizan una esquizogonia para producir merozoitos. Los merozoitos se diseminan en el hospedador intermediario por vía sistema sanguíneo (Leguía y Clavo, 1989).

Varias especies de Sarcocystis han sido desarrolladas in vitro, empleando tanto cultivo de líneas celulares como cultivo primario de células (Fayer, 1970; Speer et al., 1986 a,b; Cawthorn et al., 1990; Davis et al., 1991; Murphy y Mansfield, 1999). El objetivo del presente trabajo fue la reproducción de estadios asexuales (cistozoitos) de Sarcocystis aucheniae en cultivo de células, a fin de mantener merozoitos en el laboratorio que puedan ser utilizados en investigaciones sobre el tratamiento y prevención de la sarcocistiosis en camélidos sudamericanos.

\section{Materiales y Métodos}

\section{Aislamiento de S. aucheniae}

Organismos móviles en forma de banana fueron obtenidos de macroquistes de
S. aucheniae extraídos de musculatura esquelética de alpacas con sarcocistiosis. Los macroquistes fueron tratados con un homogenizador eléctrico para liberar los cistozoitos. Los parásitos fueron suspendidos en 2-3 ml de solución salina balanceada de Hanks (HBSS) y antibióticos. Fueron pasados por varias capas de gasa estéril para remover restos de tejido de las membranas del quiste, y centrifugados a $290 \mathrm{~g}$ por $5 \mathrm{mi}-$ nutos. Los cistozoitos fueron resuspendidos en el medio mínimo esencial Dulbecco (MEM) y se contaron 350,000 organismos aproximadamente con una cámara de Neubauer, y colocados en frascos de cultivo.

Los cistozoitos fueron desarrollados y mantenidos en cultivo primario de cornete nasal de feto de alpaca (CNA) y cultivo de líneas celulares de riñón de bovino (BHK) y riñón de mono africano (Cercopithecus aehiops) (VERO). Las células hospedadoras se desarrollaron en frascos de plástico de 25 $\mathrm{cm}^{2}$ en el medio mínimo esencial Dulbecco (MEM), suplementado con $10 \%$ de suero fetal de bovino (SFB), 100 UI penicilina, 100 mg estreptomicina y $0.25 \mu \mathrm{g} / \mathrm{ml}$ de anfotericin B. Formada la monocapa, el medio de crecimiento fue reemplazado por el medio de mantenimiento, donde la concentración de SFB fue de $2 \%$. Los cultivos celulares fueron incubados a $37{ }^{\circ} \mathrm{C}$ en una atmósfera conteniendo $5 \%$ de $\mathrm{CO}_{2}$ y $95 \%$ de aire. Las células, una vez infectadas, fueron examinadas diariamente con un microscopio invertido para determinar el desarrollo de lesiones en la monocapa o la replicación del parásito.

\section{Técnicas Inmunoserológicas}

Para confirmar la presencia dentro de las células hospederas o la replicación de los parásitos se utilizaron dos pruebas inmunológicas: Inmunoperoxidasa e inmunofluorescencia indirecta utilizando un antisuero específico anti $S$. aucheniae producido en conejos inmunizados con lisados de macroquistes de S. aucheniae. Así mismo, los parásitos y su replicación fueron examinados con tinción Giemsa. 
(a)

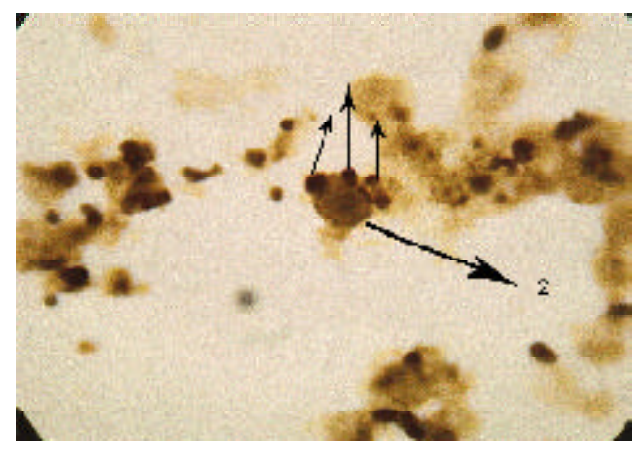

(b)

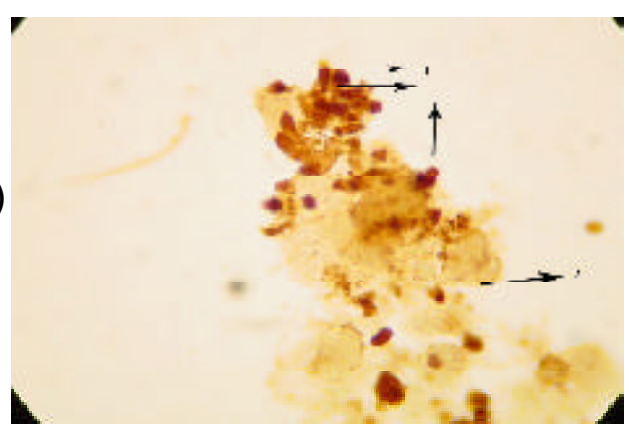

Figura 1. Presencia de cistozoitos de Sarcocystis aucheniae en cultivo primario de cornete nasal de feto de alpaca (CNA) en la prueba de Inmunoperoxidasa (a) Los cistozoitos se encuentran en posición perinuclear (1). Se observa, además, el núcleo de la célula (2), 1000x. (b) Los cistozoitos en el cultivo con células de riñón de mono africano (VERO) toman la coloracion marrón (1), mientras que las células VERO se tornan de color amarillo (2).

\section{Resultados y Discusión}

Los organismos ingresaron a todas las células, transformándose, en su mayoría, en formas elipsoides y ovoides con núcelo hipercromático, y otros en minoría con nucleos menos denso y de mayor tamaño con apariencia de mórula y de posición perinuclear. Las células CNA fueron más sensibles, seguidas de las VERO y las BHK.

A la inmunoperoxidasa se observan formas alargadas ovoides de color marrón oscuro, dentro y fuera de las células, que indican la presencia de los esporozoitos en proceso de multiplicación, mientras que las células tienen un tenue color amarillento a pardo claro (Fig. 1). En la prueba de inmunofluorescencia se encuentran formas alargadas y ovoides fluorescentes, sobre un fondo oscuro en donde se observan células con un citoplasma oscuro pero con un reborde verdoso opaco que delimita a la membrana citoplasmática (Fig. 2).

A la tinción con Giemsa se observa la presencia de esporozoitos dentro y fuera de las células, transformados en formas alargadas, elipsoides, teñidas de color basófilo tenue y otras más coloreadas sobre un fondo rosáceo-azulado, característicos del citoplas- ma celular, y con presencia de detritos celulares amorfos (Fig. 3).

El presente estudio consiguió desarrollar cistozoitos de $S$. aucheniae en cultivo celular. La viabilidad de los cistozoitos se demostró cuando estos no se colorearon con el azul de tripán debido a que este colorante es un coloide de acción intravital, por lo tanto solo se introduce en el interior de las células no viables que presentan roturas en la membrana (Worth, 1962).

Como es difícil identificar todos los estadios del parásito en los cultivos de células a través de un microscopio invertido (100x), la presencia de los cistozoitos y su multiplicación fue confirmada con el uso de las técnicas de inmunoperoxidasa e inmunofluorescencia. Estos, al reaccionar con el suero hiperinmune específico contra el lisado de macroquistes de $S$. aucheniae, permite observar formas ovoides de color marrón oscuro dentro y fuera del citoplasma.

A partir del tercer día de la primera infección con esporozoitos en células VERO, se observó una vacuolización de las células, la misma que al cuarto día llegó llegó al 80\%. En la monocapa de células BHK, se observó un 20 y $40 \%$ de vacuolizacion a partir del 
(a)

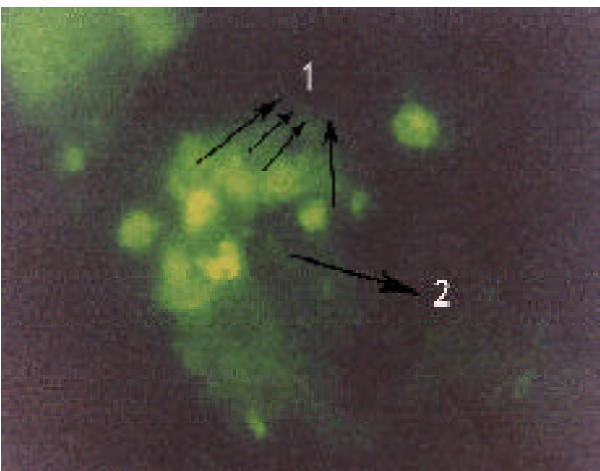

(b)

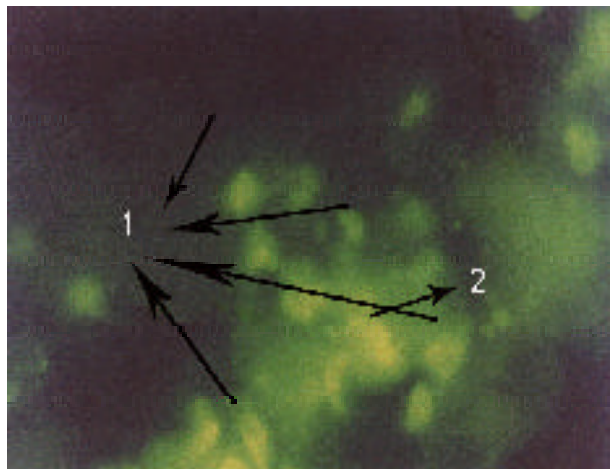

Figura 2. Presencia de cistozoitos de Sarcocystis aucheniae en cultivo primário de cornete nasal de feto de alpaca (CNA) en la prueba de Inmunofluorescencia, 1000x. (a) Células CNA. Los cistozoitos se encuentran en posición perinuclear (1). Se observa el núcleo (2). (b) Células Vero. Presencia de formas elipsoides de crecimiento (1) y la típica forma de banana (2)
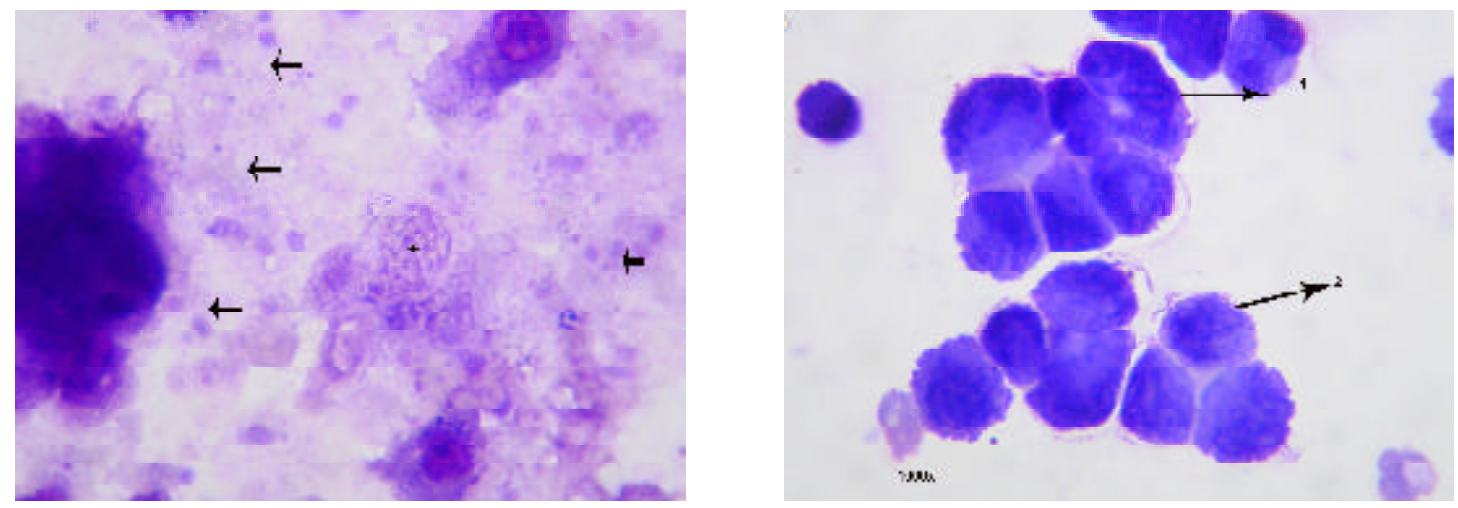

Figura 3. Células VERO infectadas con cistozoitos de S. aucheniae (a) y no infectadas (b), teñidas con tinción Giemsa, 1000x. a) Presencia de cistozoitos (flecha). Esquizonte con núcleo en forma de mórula que contiene varios nucleolos (estrella), (b) Células con núcleo de gran tamaño (1) y citoplasma reducido (2).

$3^{\text {er }}$ y $4^{\text {to }}$ día, respectivamente. La destrucción fue de un $20 \%$ de la monocapa celular. Es probable que esta vacuolización se deba a la presencia de cuerpos residuales, tal como ha sido frecuentemente reportado (Davis et al., 1991; Lindsay et al., 1999; Dubey et al., 2000) en cultivos primarios, así como en líneas celulares establecidas.

\section{ConClusiones}

? Los estadios asexuales del Sarcocystis aucheniae se pueden reproducir in vitro en células embrionales de cultivo primario y en células de tejidos y en líneas celulares establecidas. 
? Las células de cornete nasal de alpaca son más sensibles a la infección por cistozoitos de $S$. aucheniae que células establecidas de riñón de mono (VERO) y de riñón de bovino (BHK).

? Los cistozoitos de S. aucheniae reproducidos en cultivos celulares mantienen sus características inmunogénicas.

\section{Literatura Citada}

1. Alva J, Rojas M, Núñez A. 1980. Decomisos por parasitosis y su importancia económica en alpacas (Lama pacos). Rev Inv Pec (IVITA) 5(1): 61-62.

2. Cawthorn RJ, Markham F, Hitt ND, Despres D. 1990. In vitro cultivation of the vascular phase of Sarcocystis hirsute (Apicomplexa). Can J Zool 68: 1068-1070.

3. Davis SW, Speer CA, Dubey JP. 1991. In vitro cultivation of Sarcocystis neurona from the spinal cord of a horse with equine protozoal myelitis. J Parasitol 77: 789-792.

4. Dubey JP, Speer CA, Lindsay DS. 2000. In vitro cultivation of schizonts of Sarcocystis speeri Dubey and Lindsay, 1999. J Parasitol 86: 671-678.

5. Fayer R. 1970. Sarcocystis: Development in cultured avian and mammalian cells. Science 168: 1104-1105.
6. Leguía G, Clavo N. 1989. Sarcocystiosis o «Triquina». Boletín Técnico $\mathrm{N}^{\circ} 7$. CICCS UNMSM CI IVITA. Lima. p 5-19.

7. Lindsay DS, Dubey JP, Horton KM, Bowman DD. 1999. Development of Sarcocystis falcatula in cell cultures demonstrates that it is different from Sarcocystis neurona. Parasitology 118: 227-233.

8. Moro M, Guerrero C. 1971. La alpaca. Enfermedades infecciosas y parasitarias. Bol. Div. IVITA-UNMSM 8: 41-42.

9. Murphy AJ, Mansfield LS. 1999. Simplified technique for isolation, excystation, and culture of Sarcocystis species from opossums. J Parasitol 85: 979-981.

10. Sam RE. 1988. Sarcocystis aucheniae: Caracterización parcial de componentes antigénicos y patología clínica experimental en alpacas. Tesis Doctoral. Lima: Facultad de Ciencias Biológicas, Univ. Nacional Mayor de San Marcos. 118 p.

11. Speer CA, Whitmire WM, Reduker DW, Dubey JP. 1986a. In vitro cultivation of meronts of Sarcocystis cruzi. J Parasitol 72: 677-683.

12. Speer CA, Cawthorn RJ, Dubey JP. 1986b. In vitro cultivation of the vascular phase of Sarcocystis capracanis and Sarcocystis tenella. J Protozool 33: 486-489.

13. Worth H. 1962. Histología. $3^{\text {ra }}$ ed. México: Ed. Interamericana. 823 p. 